\title{
Characterization by NMR of Ozonized Methyl Linoleate
}

\author{
Maritza F. Díaz ${ }^{*, a}$ and José A. Gavín \\ ${ }^{a}$ Department of Ozonized Substances, Ozone Research Center, National Center for Scientific Research, \\ P.O. Box 6412, Havana, Cuba \\ ${ }^{b}$ University of the Laguna 38207, Tenerife, Spain
}

\begin{abstract}
No presente estudo o linoleato de metila ozonizado com índice de peróxidos de 1.800 mmol-equiv. $\mathrm{kg}^{-1}$ foi caracterizado quimicamente. Os efeitos do ozônio sobre o linoleato de metila produz hidroperóxidos, ozonideos e aldeídos, os quais foram identificados por técnicas de ressonância magnética nuclear de ${ }^{1} \mathrm{H}$ e ${ }^{13} \mathrm{C}$, mono- e bidimensional. O linoleato de metila padrão e o linoleato de metila ozonizado mostram espectros muito similares, excetuando os valores de ressonância $(\delta 9,7$ e $\delta 9,6)$ que correspondem aos hidrogênios aldeídicos $(\delta 5,7$ e $\delta 5,5)$ e olefínicos de hidroperóxidos $(\delta 5,2)$. Outras atribuições estão baseadas nas conectividades fornecidas pelas constantes de acoplamento. Estes resultados indicam que a espectrometria de RMN pode oferecer informação valiosa a respeito da quantidade de compostos oxigenados formados à partir do linoleato de metila ozonizado para o uso em ozonoterapia e na química de óleos vegetais ozonizados.
\end{abstract}

In the present study ozonized methyl linoleate with peroxide index of $1,800 \mathrm{mmol}$-equiv $\mathrm{kg}^{-1}$ was chemically characterized. Ozonation of methyl linoleate produced hydroperoxides, ozonides and aldehydes which were identified by ${ }^{1} \mathrm{H}$ and ${ }^{13} \mathrm{C}$ NMR two-dimensional. The standard methyl linoleate and ozonized methyl linoleate shown very similar ${ }^{1} \mathrm{H}$ NMR spectra except for the signals at $\delta 9.7$ and $\delta 9.6$ that correspond to aldehydic hydrogen, $\delta 5.7$ and $\delta 5.5$ (olefinic signals from hydroperoxides) and $\delta 5.2 \mathrm{ppm}$ (multiplet from ozonides methynic hydrogen). Other resonance assignments are based on the connectivities provided by the hydrogen scalar coupling constants. These results indicate that NMR spectroscopy can provide valuable information about the amount of formed oxygenated compounds in the ozonized methyl linoleate in order to use it to follow up ozone therapy and chemistry of ozonized vegetable oil.

Keywords: methyl linoleate, ozone, ozonides, aldehydes, NMR

\section{Introduction}

Linoleic acid is one of the most important components of vegetable oils and lipids. ${ }^{1}$ The determination of molecular structure of ozonized fatty acids is one of aim of scientists which work with ozonized vegetable oils and ozone therapy. ${ }^{2}$

Many studies have been carried out to develop new analytical techniques that, with very little or any manipulation of the sample, can afford the identification of the vegetable oil and lipids. ${ }^{3,4}$ Specifically, one spectroscopic technique with a high potential in this field is High-Resolution Nuclear Magnetic Resonance Spectroscopy. Both ${ }^{1} \mathrm{H}$ and ${ }^{13} \mathrm{C}$ NMR have already been

*e-mail: maritza.diaz@cnic.edu.cu employed in the analysis of vegetable oil and biological samples such as lipids. ${ }^{5,6}$ However, data on the spectra of ozonized fatty acids is scarce in the literature.

The reaction of ozone with vegetable oil and lipids occurs almost exclusively with the carbon-carbon double bonds present in unsaturated fatty acids. Different kinds of oxygenated products are formed (hydroperoxides, ozonides and aldehydes) that probably are responsible for the biological activity of ozonized fatty acids. ${ }^{7-9}$ The mechanism of this reaction is well known (Criegee mechanism, Figure 1), as well as the conditions necessary to enhance the preferential formation of any of these oxygenated compounds..$^{10,11}$

Of all the natural fatty acids, linoleic acid is one of the most widely distributed and is present in practically all lipids. For this reason, methyl linoleate was chosen as a model compound to be ozonized and chemically 


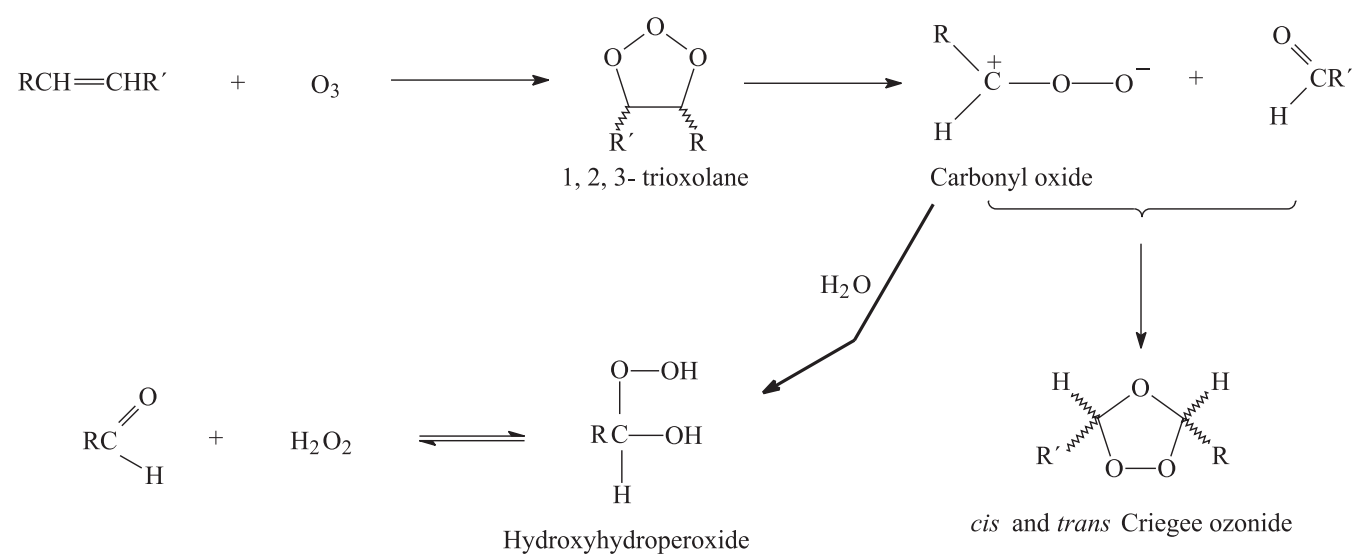

Figure 1. Mechanism of reaction of ozone with unsaturated fatty acids.

characterized. In this study the products of ozonized methyl linoleate were analyzed applying ${ }^{1} \mathrm{H},{ }^{13} \mathrm{C}$ and $2 \mathrm{D}$ COSY NMR spectroscopy.

\section{Experimental}

\section{General ozonization procedure}

A mixture of $1.6 \mathrm{~mL}\left(0.0048 \mathrm{~mol} \mathrm{~L}^{-1}\right)$ of methyl linoleate $(99 \%)$ and $0.16 \mathrm{~mL}$ of water were introduced into a bubbling reactor where ozone reaction took place at room temperature. ${ }^{7,8}$ The reaction was continued during 7.25 minutes and one sample was taken at applied ozone doses $245 \mathrm{mg} \mathrm{g}^{-1}$. The samples were stored at $-80{ }^{\circ} \mathrm{C}$ until NMR analysis. Methyl linoleate were purchased from Sigma Chemical Co. (St. Louis, MO).

\section{Ozone generation}

Ozone was generated by passing oxygen through a 12-02 model ozone generator of Trailigaz Company (France) at a fixed voltage $(170 \mathrm{~V})$ and constant flow rate of $42 \mathrm{~L} \mathrm{~h}^{-1}$. The initial ozone concentration $\left(69 \mathrm{mg} \mathrm{L}^{-1}\right)$ was determined by an Ozomat model equipment of Anseros Company (Germany).

\section{Measurement of NMR spectra}

${ }^{1} \mathrm{H},{ }^{13} \mathrm{C}$, DEPT 135 and 2D COSY NMR spectra were obtained in a BRUKER 9.4 Tesla AVANCE Spectrometer with $\mathrm{CDCl}_{3}$ as solvent and tetramethylsilane (TMS) as internal reference. The ${ }^{1} \mathrm{H}$ NMR spectra were obtained at $5 \mathrm{kHz}$ spectral width, 60 degree pulse width $(5 \mu \mathrm{s})$, 8 scans, and 64 kbytes of memory were used to obtain the spectra. ${ }^{13} \mathrm{C}$ NMR spectra were recorded operating at $100 \mathrm{MHz}$ and were obtained using the following acquisition parameter: $64 \mathrm{k}$ of acquisition point; spectral width $220 \mathrm{ppm}$; relaxation delay, $2 \mathrm{~s}$; a total of 800 scans was collected for sample with a $45^{\circ}$ excitation pulse. The experiment (distortionless enhancement by polarization transfer, DEPT) were obtained using variable pulse $\theta=135^{\circ}$. The $2 \mathrm{D}^{1} \mathrm{H}^{-1} \mathrm{H}$ correlation spectroscopy (COSY) and Heteronuclear Simple Quantum Correlation (HSQC) spectra were obtained with a digital resolution of $5.425 \mathrm{~Hz}$ after zero filling. Zero filling (one) were done in the F1 dimension of a $512 \times 512$ matrix, the data were $2 \mathrm{D}$ transformed and the magnitude spectra multiplied by a sine window in each dimension and symmetrized along the diagonal. ${ }^{12}$

\section{Peroxide index determination}

The peroxide index represents the number of mmolequivalents of active oxygen that expresses the amount of peroxide contained in $1.000 \mathrm{~g}$ of the methyl linoleate. Briefly, a sample of $5 \mathrm{~g}$ was mixed with 30 volumes of glacial acetic, 20 volumes of chloroform and $0.5 \mathrm{~mL}$ of saturated potassium iodide solution. The mixture was shacked for exactly 1 minute, mixed with $30 \mathrm{~mL}$ of water and slowly titrated; shaking continuously, with $0.01 \mathrm{~mol}$ $\mathrm{L}^{-1}$ sodium thiosulphate until the yellow color almost disappears. The peroxide index values were obtained from the expression $10 \mathrm{v} / \mathrm{m}$ where $\mathrm{v}$ is the volume of sodium thiosulphate in $\mathrm{mL}$ consumed in the titration, and $\mathrm{m}$ is the weight in $\mathrm{g}$, of substance taken..$^{13}$ The peroxide index (PI) was expressed in mmol-equiv. $\mathrm{kg}^{-1}$.

\section{Results and Discussion}

The aim of this study was to characterize oxygenated products in ozonized methyl linoleate. Since vegetable oils and lipid consist almost entirely of triglycerides 
molecules, no appreciable difference was anticipated between the chemical shift values of these vegetable oils and their component esterified fatty acids. ${ }^{14}$ In our experiment for preparation of ozonized methyl linoleate, about $245 \mathrm{mg} \mathrm{g}^{-1}$ of ozone was absorbed per $1.6 \mathrm{~mL}$ of methyl linoleate which seemed to be enough to obtain ozonized methyl linoleate with 1,800 mmol-equiv. $\mathrm{kg}^{-1}$ of peroxide index. Scheme 1 shows possible ozonides, hydroperoxides and aldehydes can be obtained in ozonized methyl linoleate.
Figure 2 shows ${ }^{1} \mathrm{H}$ NMR spectrum from methyl linoleate, presenting a single peak at $\delta 7.3$ which belongs to the chloroform-d, multiplet peaks at $\delta 5.3$ which belong to olefinic signals from the fatty acid, $\delta 3,6$ (single peak from methylic hydrogen of ester), $\delta 2.7$ (triplet from methylenic group between olefinic hydrogen); $\delta 2.3$ (triplet from methylenic groups in $\alpha$ position with respect to carbonylic group); $\delta 2.0$ (multiplet from methylenic group in both sides of olefinic hydrogen); $\delta 1.6$ (multiplet from methylenic group in $\beta$ position with respect to carbonylic

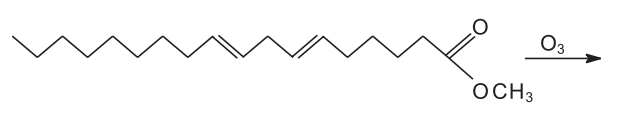

Methyl Linoleate<smiles>[2H]C1OOC([2H])O1</smiles>

Ozonides<smiles></smiles>

Hydroperoxides Aldehydes

OZONIDES<smiles>CCCCCCCCC1OOC(C/C=C/CCCCC(=O)OC)O1</smiles>

PM-342<smiles>CCCCCCCC/C=C/C=C1OC=C(CCCC(=O)OC)O1</smiles>

PM-342<smiles>CCCCCCCCC1OOC(CC2OOC(CCCCC(=O)OC)O2)O1</smiles>

PM -390

HYDROPEROXIDES<smiles>CCCCCCCCC(O)O</smiles><smiles>CCCCCCCC/C=C/CC(O)O</smiles><smiles>COC(=O)CCCC/C=C/CC(O)O</smiles><smiles>COC(=O)CCCCC(O)O</smiles>

PM- 176<smiles>CCCCCCCCC=O</smiles><smiles>CCCCCCCCC/C=C/CC=O</smiles>

PM- 216

PM-218<smiles>COC(=O)CCCC/C=C/CC=O</smiles><smiles>COC(=O)CCCCC=O</smiles>

PM- 142

PM- 181

PM-184

PM - 144

$\mathrm{PM}-178$

Scheme 1. Oxygenated compounds obtained of the reaction of ozone with methyl linoleate. 

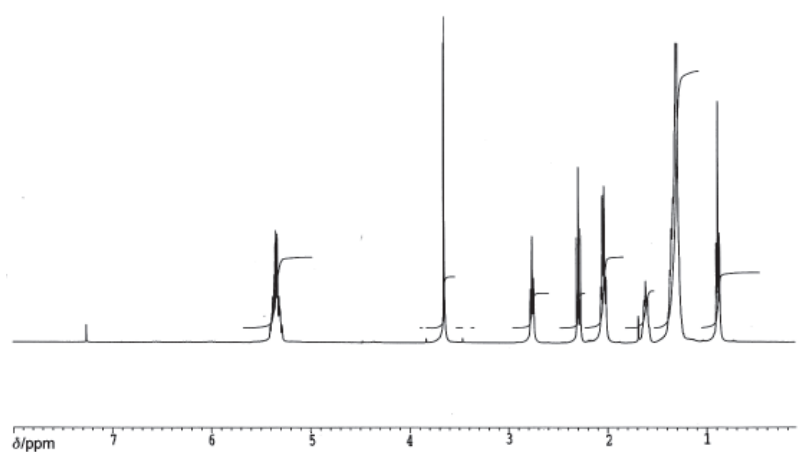

Figure 2. ${ }^{1} \mathrm{H}$ NMR spectrum of methyl linoleate in $\mathrm{CDCl}_{3}$ in 9.4 Tesla equipment.

group); $\delta 1.3$ (signal from methylenic groups in fatty acid chain); and $\delta 0.9$ (triplet from terminal methyl group).

${ }^{1} \mathrm{H}$ NMR spectrum from ozonized methyl linoleate is displayed in Figure 3. This spectrum has the same observed signals in methyl linoleate (Figure 2) and additionally other eight signals at $\delta 9.7$ and $\delta 9.6$ from aldehydic hydrogen, $\delta 5.7$ and $\delta 5.5$ (olefinic hydrogen signal from hydroperoxides), $\delta 5.2$ (multiplet from ozonides), $\delta 3.2$ (doublets from methylenic hydrogen alilic of olefinic hydrogen), $\delta 2.4$ and $\delta 1.62$ (multiplet from formed ozonides hydrogen). These formed additionally signals are oxygen compounds which seem to be responsible for the germicide effect of ozonized vegetable oil and metabolites generated by application of systemic ozone therapy. ${ }^{15-17}$
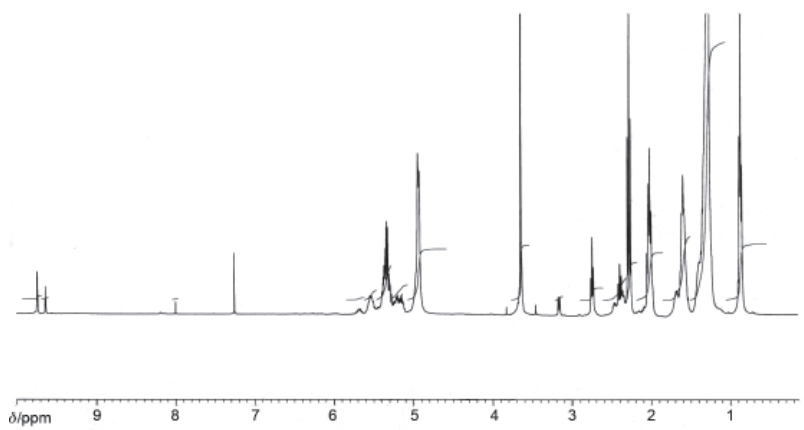

Figure 3. ${ }^{1} \mathrm{H}$ NMR spectrum of ozonized methyl linoleate in $\mathrm{CDCl}_{3}$ in 9.4 Tesla equipment.

The ${ }^{13} \mathrm{C}$ NMR spectrum of methyl linoleate contains resonance similar of carbons from the triglyceride fraction of vegetable oil, i.e., the fatty acid signals. ${ }^{18,19}$ However a new group of signals were found in the spectrum from ozonized methyl linoleate (Figure 4). The ${ }^{13} \mathrm{C}$ NMR espectrum are grouped in four sets of signals, aldehyde carbons resonating from $\delta 199.0$ to $\delta 203.0$, carbonyl carbon resonance from $\delta 174.4$, unsaturated carbons in the range from $\delta 127.0$ to $\delta 136.0 \mathrm{ppm}$, methynic carbons corresponding to ozonides at $\delta 100.0$ to $\delta 104.0$, and aliphatic carbons from $\delta 14.0$ to $\delta 44.0$.
Spectral region $\delta$ 14.0-44.0

Figure 4 and 5 shows ${ }^{13} \mathrm{C}$ and DEPT NMR spectra from ozonized methyl linoleate. The aliphatic carbons of methyl and methylenic groups resonate in the range of $\delta$ 14.0-44.0. The different signals are resolved on the basis of chain double bond numbers: linoleic chains (C18:2 $9,12 \mathrm{c}$ ) resonate from high to low frequency. The chemical shift can be predicted by the additive relationship for the normal alkanes based upon the number of $\alpha, \beta$ and $\gamma$ carbon atoms in the molecule. ${ }^{20}$ The terminal methyl carbon shift $\mathrm{C}-18$ is found at $\delta 14 \mathrm{ppm}$. Four methylene groups are readily identified: $\mathrm{C}-17$ at $\delta 22.5$ methylenic acylic chains; C-3 at $\delta 24.9, \delta 24.3$ and $\delta 24.2$ methylenic group in $\beta$ position with respect to carbonylic group; $\mathrm{C}-11$ at $\delta 25.6$ methylenic group between olefinic hydrogen of linoleic chains; C-11, C-14, and C-8, at $\delta 27.1, \delta 27.5$ allylic carbons of linoleic chains; $\delta$ 29.029.5 methylenic groups in fatty acid central chain; C-16 at $\delta 31.5$ methylenic acylic chains $\omega ; \mathrm{C}-2$ at $\delta 34.0$ linoleic as a single signal but well resolved from saturated chains. New signals were observed at $\delta 24.9, \delta 24.3$, and $\delta 24.2$ belong

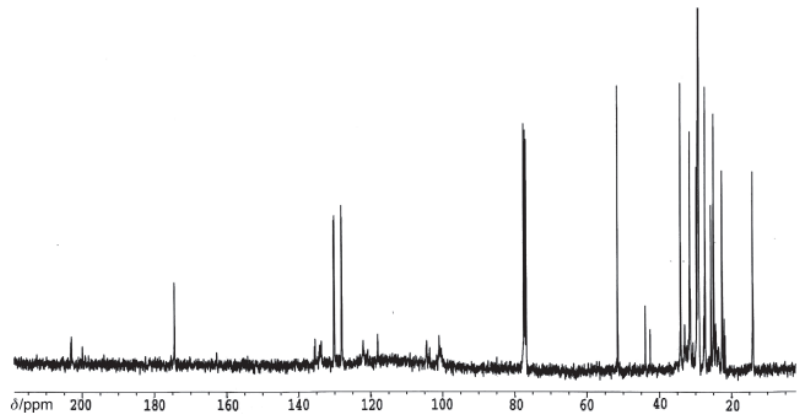

Figure 4. ${ }^{13} \mathrm{C}$ NMR spectrum of ozonized methyl linoleate in $\mathrm{CDCl}_{3}$ in a 9.4 Tesla equipment.

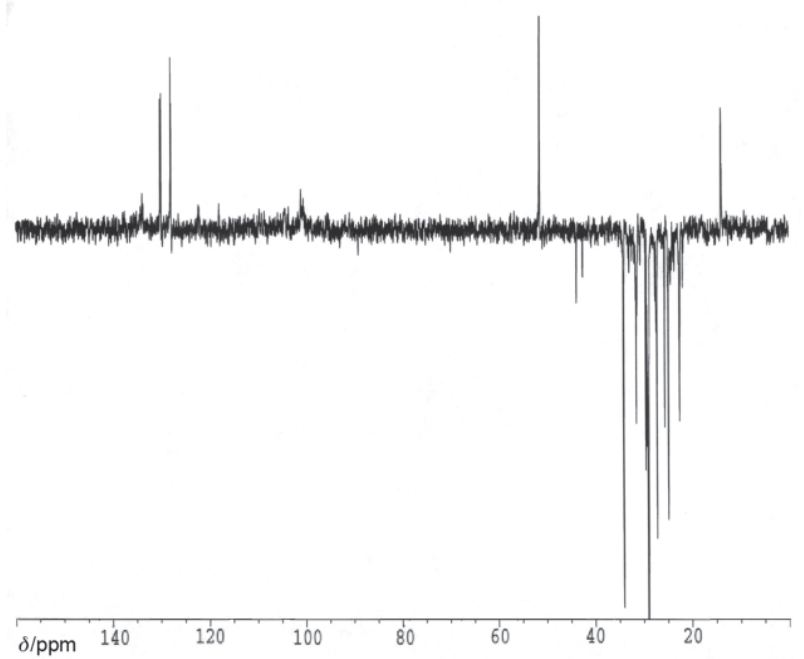

Fgure 5. DEPT135 NMR spectrum of ozonized methyl linoleate in $\mathrm{CDCl}_{3}$ in a 9.4 Tesla equipment. 
to methylenic carbons of ozonides and methylenic carbons of ozonides and hydroperoxides at $\delta 42.5$ and $\delta 43.8$.

\section{Spectral region $\delta$ 127.0-136.0}

The resonance of unsaturated carbons of long chain of ozonized methyl linoleate spread over the chemical shift range from $\delta$ 127.0-136.0. The carbons C-9 at $\delta 127.9, \mathrm{C}-10$ at $\delta 130.0, \mathrm{C}-12$ at $\delta 128.0$ and $\mathrm{C}-13 \delta$ 130.1 corresponding to linoleic unsaturated carbons. The additional signals at $\delta 133.6, \delta 135.3$ and $\delta 135.5$ methynic carbons corresponding to ozonides and hydroperoxides.

\section{Spectral region signals $\delta$ 102.0-105.0}

In this spectral region signals corresponding to methynic carbons of ozonides appear at $\delta 103.5$ and $\delta 104.3$.

\section{Spectral region $\delta$ 174.0-203.0}

In this spectral zone the carbonyl carbons at $\delta 174.4$ belong to ester function can observed and also the aldehydes carbons resonating at $\delta 199.8, \delta 202.9$ and $\delta 203.1$.

The DEPT experiment was applied to obtain ${ }^{13} \mathrm{C}$ NMR spectra over the whole carbon-13 frequency range with the purpose of producing ${ }^{13} \mathrm{C}$ NMR resonance for better structural elucidation. The only drawback was the loss of carbonyl carbons resonance, which is not detected by the DEPT sequence $\left(\right.$ Freeman $^{21}$ ).

The assignments of the various signals were accomplished by using a combination of $2 \mathrm{D} \operatorname{COSY}$ techniques ${ }^{1} \mathrm{H}-{ }^{1} \mathrm{H}$ and HSQC (Figure 6 and 7). To explain the detailed interpretation of the ${ }^{1} \mathrm{H}-{ }^{1} \mathrm{H}$ NMR COSY spectra, the ${ }^{1} \mathrm{H}$ NMR spectrum showed six new signals: $\delta 5.7, \delta 5.5, \delta 5.2, \delta 3.2, \delta 2.4$ and $\delta 1.6$. From the ${ }^{1} \mathrm{H}-{ }^{1} \mathrm{H}$ NMR COSY correlation spectrum (Figure 6), it was clear that the multiplet at $\delta 5.5$ (olefinic hydrogen signal could belong to hydroperoxides) was correlated to the hydrogen at $\delta 3.2$ (doublets from methylenic hydrogen alilic of olefinic hydrogen); and $\delta 5.2$ (multiplet from ozonides) was correlated to the $\delta 2.4$ and $\delta 1.6$ (multiplet from formed ozonides hydrogen).

The ${ }^{13} \mathrm{C}$ spectrum showed various new signals: $\delta 135.5$ $133.6 ; \delta 122.0-118.0 ; \delta 104.4-100.9 ; \delta 43.8 ; \delta 42.5 ; \delta 23.5-$ 23.9. From the HSQC correlation spectrum (Figure 7), we observed that the multiplet at $\delta_{\mathrm{H}} 5.7$ was correlated to the carbon atoms $\delta_{\mathrm{C}}$ 135.5-135.3 and the multiplet $\delta_{\mathrm{H}} 5.5$ was correlated to the carbon atom $\delta_{\mathrm{C}} 133.6$ spectral region of unsaturated carbons. The multiplet $\delta_{\mathrm{H}} 5.2$ was correlated to the carbon atoms $\delta_{\mathrm{C}} 104.4$, $\delta_{\mathrm{C}} 103.5$ and $\delta_{\mathrm{C}} 100.9$, they belong to methynic carbons

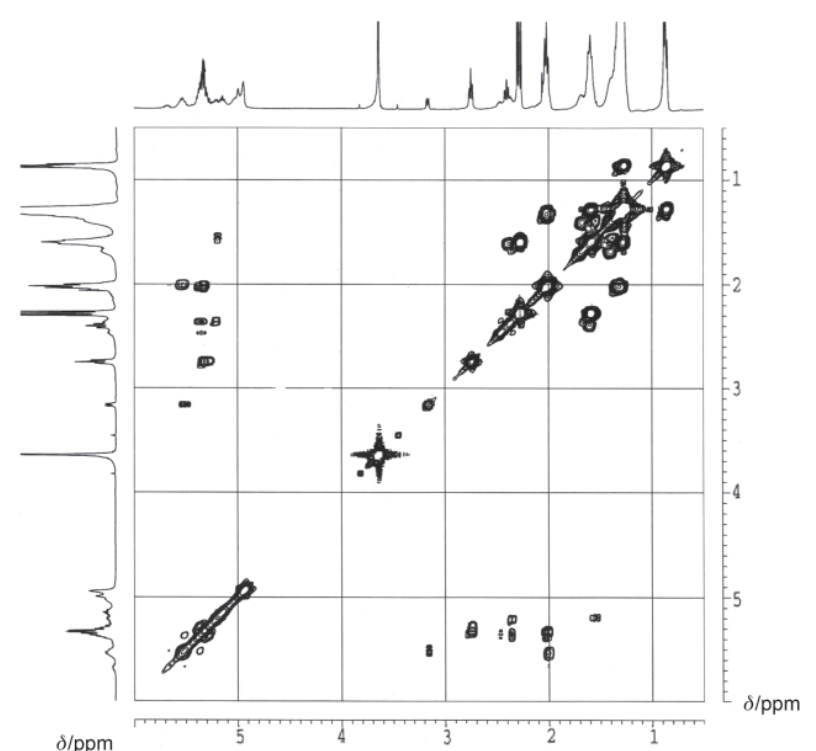

Figure 6. ${ }^{1} \mathrm{H}-{ }^{1} \mathrm{H}$ NMR correlation spectroscopy $2 \mathrm{D}$ NMR spectrum of ozonized methyl linoleate in 9.4 Tesla equipment.

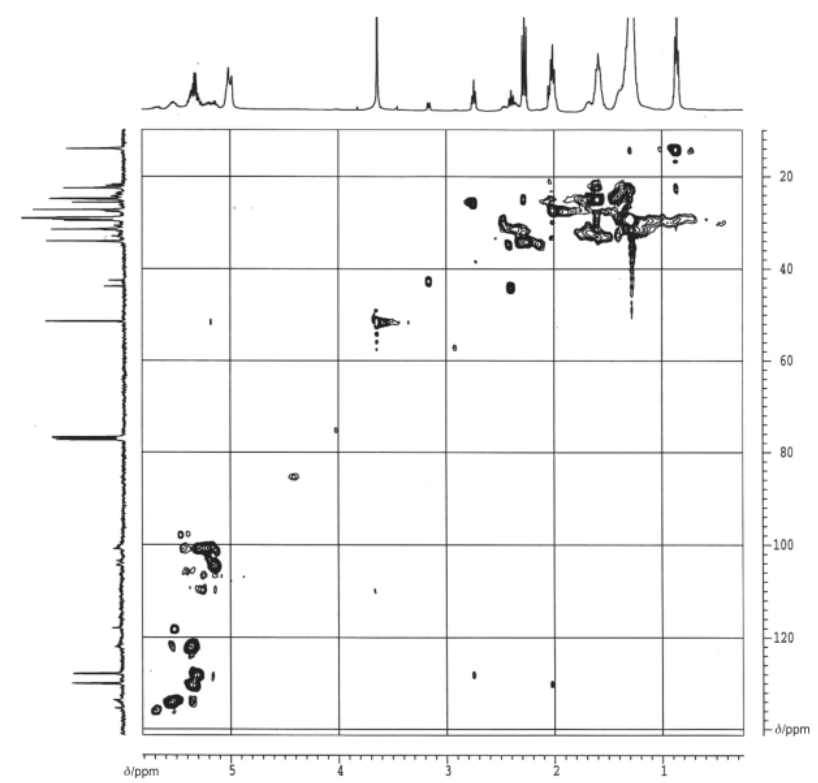

Figure 7. HSQC correlation spectrum of ozonized methyl linoleate in 9.4 Tesla equipment.

from ozonides and oligomers. These assignations are similar to those reported by Miura working with ozonated olive oil..$^{22}$ Signal of methylenic carbon at $\delta_{\mathrm{C}} 43.8$ was correlated to the $\delta_{\mathrm{H}} 2.4$ of ozonides. Other signal of methylenic carbon at $\delta_{\mathrm{C}} 42.5$ was correlated to the $\delta_{\mathrm{H}} 3.2$ (doublets from methylenic hydrogen alilic of olefinic hydrogen).

For a better explaination, Table 1 shows the main chemical shift and structures of the oxygenated compound of ozonized methyl linoleate. In the structural elucidation of the ozonized methyl linoleate, the assignments of various signals (ozonation products) were accomplished by using a combination of $2 \mathrm{D} \operatorname{COSY}$ 
Table 1. Ozonized methyl linoleate functional group chemical shift (ppm)

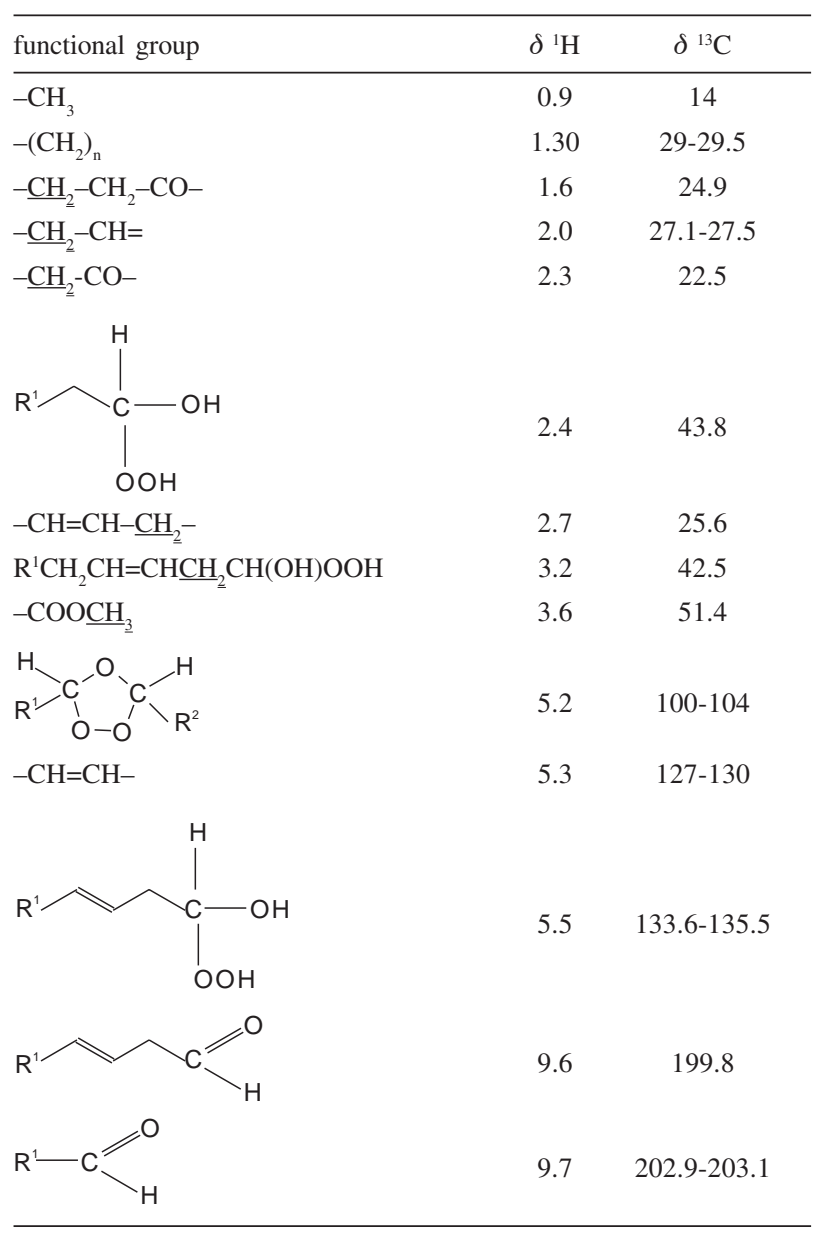

techniques ${ }^{1} \mathrm{H}-{ }^{1} \mathrm{H}$ and $\mathrm{HSQC}$ with ${ }^{1} \mathrm{H}$ and ${ }^{13} \mathrm{C}$ NMR spectra. In this study all functional groups of the ozonation products were well characterized as ozonides, hydroperoxides and aldehydes present in ozonized methyl linoleate. These reaction products were identified according to Criegee mechanism. ${ }^{10}$ The ozonides of methyl oleate have been considered compounds with biological activity, which has been demonstrated by Díaz et al..$^{15}$ The elucidation and chemical characterization of reaction products from ozonized methyl linoleate are important for ozone therapy follow up and new ozonation strategies with vegetable oils.

\section{Acknowledgments}

We wish to thank CYTED and INTERCAMPUS for providing financial support. Appreciation is expressed to Dr. Angel Gutiérrez Ravelo, University of the Laguna, Tenerife, for his collaboration in this work.

\section{References}

1. Vajda, O.I.; Saenz, T.W.; Química de los Alimentos, Editorial Científico Técnico: La Habana, 1976, ch. 1.

2. Pryor, W.A.; Squadrito, G.L.; Friedman, M.; Free Radic. Biol. Med. 1995, 19, 935.

3. Zamora, R.; Alba, V.; Hidalgo, J.F.; J. Am. Oil Chem. Soc. 2001, $78,89$.

4. Gunstone, F.D. In High Resolution ${ }^{13} \mathrm{C}$ NMR Spectroscopy of Lipids, Advances in Lipid Methodology-Two; Christie, W.W. ed., The Oily Press: Dundee, Scotland, 1993.

5. Jie, L.K.; Mustafa, M.S.F.; Lipids 1997, 78, 15.

6. Vlahov, G.; Fett/Lipid 1996, 98, 203.

7. Díaz, M.; Álvarez, I.; Vélez, H.; Hernández, F.; Ledea, O.; Molerio, J.; Bol. Soc. Chil. Quim. 1997, 42, 349.

8. Díaz, M.; Hernández, F.; Álvarez, I.; Vélez, H.; Ledea, O.; Molerio, J.; Rev. CENIC C. Quim. 1998, 29, 89.

9. Pryor, W.A.; Das, B.; Church, D.F.; Chem. Res. Toxicol. 1991, 4, 341.

10. Criegee, R.; Mechanism of Ozonolisis, $14^{\text {th }}$ ed., Angewandte Chemie Int.: England, 1975.

11. Bailey, P.; Ozonolysis of Olefins: Introduction, Initial Ozone Attack and Adduct; The Peroxides Products. Ozonization in Organic Chemistry, Academic Press: New York, USA, 1978, ch 2 .

12. Croasmun, W.R.; Carlson, M.K.; Two-Dimensional NMR Spectroscopy. Applications for Chemists and Biochemists, VCH Publishers, Inc: New York, USA, 1987.

13. British Pharmacopoeia, Appendix XF, IA, IB. Peroxide value 2000.

14. Woodbury, S.E.; Evershed, R.P.; Rossell, J.B.; J. Chromatogr. A 1998, 805, 249.

15. Díaz, M.; Lezcano, I.; Molerio, J.; Hernández, F.; Ozone Sci. Eng. 2001, 23, 35.

16. Sechi, L.A.; Lezcano, I.; Nuñez, N.; Espim, M.; Dupre, I.; Pinna, A.; J. Appl. Microbiol. 2001, 90, 279.

17. Bocci, V.; Oxygen-Ozone Therapy. A Critical Evaluation, Kluwer Academia Publishers: Dordrecht, The Netherlands, 2002.

18. Vlahov, G.; Prog. Nucl. Magn. Reson. Spectrosc. 1999, 35, 341.

19. Díaz, M.; Gavin, J.A.; Ledea, O.; Hernández, F.; Alaiz, M.; Garcés, R.; Ozone Sci. Eng. 2005, 27, 247.

20. Giovanna, V.; Recent Res. Devel. Oil Chem. 1998, 2, 189.

21. Freeman, R.; A Handbook of Nuclear Magnetic Resonance, Longman Group UK Limited: London, 1988.

22. Miura, T.; Suzuki, S.; Sakurai, S.; Matsumoto, A.; Shinriki, N.; Proceedings of the $15^{\text {th }}$ Ozone World Congress Medical Therapy Conference, London, 2001.

Received: February 15, 2006 Web Release Date: April 17, 2007 